CLINICAL STUDY

\title{
Determinants of cardiovascular risk in 2589 hypopituitary GH-deficient adults - a KIMS database analysis
}

\author{
Roger Abs, Ulla Feldt-Rasmussen ${ }^{1}$, Anders F Mattsson ${ }^{2}$, John P Monson ${ }^{3}$, Bengt-Åke Bengtsson ${ }^{4}$, \\ Miklós I Góth ${ }^{5}$, Patrick Wilton ${ }^{2}$ and Maria Koltowska-Häggström ${ }^{2,6}$ \\ Department of Endocrinology, University Hospital, Antwerp, Belgium, ${ }^{1}$ University Hospital, Copenhagen, Denmark, ${ }^{2}$ KIGS/KIMS/ACROSTUDY \\ Medical Outcomes, Pfizer Endocrine Care, Sollentuna, Sweden, ${ }^{3}$ St Bartholomew's Hospital, London, UK, ${ }^{4}$ Sahlgrenska University Hospital, \\ Göteborg, Sweden, ${ }^{5}$ National Medical Center Budapest, Hungary and ${ }^{6}$ Department of Pharmacy, Uppsala University, Uppsala, Sweden \\ (Correspondence should be addressed to R Abs; Email: rogerabs@uza.be)
}

\begin{abstract}
Objective: The aim of the present study was to clarify the relationship between GH deficiency (GHD) and some cardiovascular risk factors and to analyse the effect of GH replacement therapy in a large number of patients over a prolonged period of time.

Design: Data for analysis were retrieved from KIMS (Pfizer International Metabolic Database). Serum concentrations of total cholesterol, high-density lipoprotein (HDL)-cholesterol, low-density lipoprotein (LDL)-cholesterol and triglycerides were obtained from 2589 patients at baseline and from 1206 patients after 1 and 2 years of GH replacement therapy. Body mass index (BMI), waist and hip, resting blood pressure and body composition were also measured.

Results: At baseline, the unfavourable effects of GHD were most obvious in the lipid profile demonstrating elevated mean total and LDL-cholesterol, in the increased waist circumference and the elevated BMI. The cholesterol concentration, BMI and body composition were significantly adversely affected by a number of factors, including age, sex and the use of anti-epileptic drugs. The therapeutic effect of GH was essentially uniform across the whole population. GH replacement reduced significantly the mean total and LDL-cholesterol, the waist circumference and the fat mass and was maintained during 2 years.

Conclusions: This analysis of a large number of patients confirmed that GHD adults present with an increased cardiovascular risk. The sustained improvement of the adverse lipid profile and body composition suggests that GH replacement therapy may reduce the risk of cardiovascular disease and the premature mortality seen in hypopituitary patients with untreated GHD.
\end{abstract}

European Journal of Endocrinology 155 79-90

\section{Introduction}

Five large retrospective studies have shown that the risk of premature death is elevated in patients with hypopituitarism, receiving conventional hormone replacement therapy but not growth hormone $(\mathrm{GH})$ $(1-5)$. In three of these studies, the increased risk was due to mainly an increased prevalence of cardiovascular disease $(1,3,5)$. The excess mortality and increase in cardiovascular and cerebrovascular disease has been confirmed in a large prospective study (6). It is likely that the increased morbidity and mortality in hypopituitary patients is caused, at least in part, by untreated growth hormone deficiency (GHD) (7), although unphysiological replacement of other pituitary hormones $(8,9)$, underlying diagnosis and non-treatment of gonadotrophin deficiency (6) may also be implicated.

The hypothesis that GHD increases the risk of cardiovascular disease is supported by findings that adult patients with GHD present a series of risk factors, such as adverse lipid profiles (10-12), increased blood pressure, abnormal body composition (13, 14), increased body weight $(15,16)$, increased coagulability (17), and increased markers of inflammation (18). These multiple abnormalities promote the development of an accelerated atherosclerotic disease, as shown by decreased aortic compliance (19) and increased intimamedia thickness (20).

There is increasing evidence that $\mathrm{GH}$ replacement provides protection against the development of myocardial infarction and could thus impact on the increased mortality rate (5). The well-known favourable changes induced by GH on the different cardiovascular risk factors may explain this recent finding. The effect on body composition has been demonstrated by different techniques (21-24). GH also has a major impact on lipid metabolism (23-27). Markers of inflammation are positively influenced by GH replacement (28). As a result of GH replacement, the abnormal aortic compliance and intima-media thickness normalise $(29,30)$.

The above-mentioned studies were usually conducted on small groups of patients and over a period of short 
time. Furthermore, not all studies have revealed the same abnormalities before and the same changes after $\mathrm{GH}$ treatment (28). Recently, a meta-analysis based on these studies was published, confirming a beneficial effect, yet in total not in very large numbers of patients (31). The aim of the present analysis was to further elucidate our understanding of the association between GHD and dyslipidaemia as well as other cardiovascular risk factors, and to determine the effect of long-term $\mathrm{GH}$ replacement therapy in a large number of patients. Secondarily, we set out to determine whether the cardiovascular risk factors in these patients were influenced by variables such as age, sex and the age of onset of GHD. The patient data in this analysis were retrieved from KIMS (Pfizer International Metabolic Database), the largest database for monitoring the efficacy and safety of long-term GH replacement in GHD adults.

\section{Patients and methods}

\section{Patients}

Patients from KIMS were included in the analysis if they satisfied the following conditions: they had severe GHD indicated by a GH peak response $<3 \mu \mathrm{g} / \mathrm{l}$ after provocative testing by insulin, arginine or glucagon; they had received no GH therapy at any time before entering KIMS (naive patients, $80 \%$ ) or had received no $\mathrm{GH}$ therapy for at least 6 months prior to entry (seminaive patients, $20 \%$ ).

In total, 2589 patients (mean age, $44.2 \pm 14.6$ years) were included in the analysis. Females numbered 1263 (48.8\%; mean age $43.6 \pm 14.2$ years), of which 769 were pre-menopausal or oestrogen-supplemented (29.7\%; mean age, $39.5 \pm 12.5$ years) and 494 postmenopausal or not-oestrogen-supplemented (19.1\%; mean age, $50.1 \pm 14.4$ years) and males numbered 1326 (51.2\%; mean age, $44.8 \pm 15.0$ years). Adultonset patients accounted for $77.5 \%$ and childhood onset for $22.5 \%$.

\section{IGF-I measurements}

Until November 2002, serum insulin-like growth factor I (IGF-I) was determined by radioimmunoassay after acid-ethanol precipitation of the binding proteins (Nichols Institute Diagnostics, San Juan Capistrano, CA, USA). Then a chemiluminescence immunoassay (Nichols Advantage ${ }^{\circledR}$ System) was introduced (32). Long-term reproducibility, measured during a time period of $>1$ year, showed a $\mathrm{CV}<9 \%$ in the concentration range of $130-850 \mu \mathrm{g} / \mathrm{l}$. The assay detection limit was $30 \mu \mathrm{g} / \mathrm{l}$. All measurements were performed in a central laboratory.

\section{Lipid measurements}

Serum concentrations of total cholesterol (33), highdensity lipoprotein (HDL)-cholesterol (34) and triglycerides (35) were measured directly and expressed as mmol/l. All measurements of lipid variables were performed in the same central laboratory. Serum concentrations of low-density lipoprotein (LDL)-cholesterol were estimated using Friedewald's formula (36). Due to low accuracy, the formula was not applied when the level of triglycerides exceeded $4.5 \mathrm{mmol} / \mathrm{l}$. The conversion factors are: $1 \mathrm{mmol} / \mathrm{l}=38.5 \mathrm{mg} / \mathrm{dl}$ for cholesterol and $1 \mathrm{mmol} / \mathrm{l}=$ $90.9 \mathrm{mg} / \mathrm{dl}$ for triglycerides. The ratio of total cholesterol over HDL-cholesterol was calculated.

\section{Profile of lipids}

Mean baseline concentrations of all four lipid fractions were calculated for all 2589 patients collectively. Mean baseline lipid concentrations were also calculated for patients categorised according to age: $<20$ $(n=122), 20-29 \quad(n=382), 30-39(n=479), 40-49$ $(n=590), \quad 50-59 \quad(n=595),>60$ years $(n=421)$ and according to gender: males $(n=1326)$, premenopausal females $(n=769)$, or post-menopausal females $(n=494)$.

The percentage of patients with baseline lipid concentrations exceeding the desired target values was calculated for: total cholesterol $>5.20 \mathrm{mmol} / \mathrm{l}$ (200 mg/dl); HDL-cholesterol $<1.04 \mathrm{mmol} / \mathrm{l}(40 \mathrm{mg} / \mathrm{dl})$ in males and $<1.30 \mathrm{mmol} / \mathrm{l}(50 \mathrm{mg} / \mathrm{dl})$ in females; LDL-cholesterol $>3.38 \mathrm{mmol} / \mathrm{l}(130 \mathrm{mg} / \mathrm{dl})$; and for triglycerides $>1.65 \mathrm{mmol} / \mathrm{l}(150 \mathrm{mg} / \mathrm{dl})(37)$.

Mean baseline concentrations of total cholesterol were calculated for patients categorised according to: the time of onset (childhood- vs adulthood-onset of the disease), the estimated duration of GHD, the severity of hypopituitarism expressed as the number of pituitary hormone deficiencies present in addition to GHD, the severity of GHD expressed as the standard deviation score (SDS) for the serum IGF-I concentration, the aetiology of GHD (non-functioning pituitary adenoma, craniopharyngioma, idiopathic, prolactinoma, Cushing's disease, acromegaly, and other aetiologies), previous radiotherapy or not, body mass index (BMI), waist/hip ratio (WHR), waist circumference, smoking/non-smoking, use of anti-epileptic drugs and lipid-lowering drugs and diabetes mellitus.

To evaluate the effect of GH replacement, mean lipid concentrations were calculated for the 1 st year and 2 nd year time-points in 1206 patients and compared with their baseline concentrations. The percentage of patients with lipid concentrations exceeding the desired target values during GH replacement at these two time points was compared to the data prior to therapy. 


\section{Profile of other cardiovascular risk factors}

Resting blood pressure $(\mathrm{mmHg})$, BMI $\left(\mathrm{kg} / \mathrm{m}^{2}\right)$, WHR and waist circumference $(\mathrm{cm})$ were measured both for the group of patients contributing with baseline data only $(n=2589)$ and for the subgroup of patients contributing with data at both baseline and after 1 and 2 years of GH treatment $(n=1206)$. The percentage of patients with a blood pressure above the target value of $130 / 85 \mathrm{mmHg}$ and with a waist circumference above $102 \mathrm{~cm}$ in men and above $88 \mathrm{~cm}$ in women was also calculated (37). Body composition was measured at baseline in two different groups of patients by dualenergy X-ray absorptiometry (DXA) or by bio-impedance analysis (BIA) with assessment of estimated values for lean and fat. In a subgroup of patients, both measurements were repeated after 1 and 2 years of $\mathrm{GH}$ replacement. Both DXA and BIA measurements were performed by a variety of different methods from each individual's participating centre without any attempts to obtain uniform calibration. The baseline data were categorised according to the same factors as mentioned for total cholesterol, although numbers in each individual group were not identical to those for cholesterol, due to missing values. The numbers are mentioned in Results section and also in Tables 1-4.

\section{Statistics}

To study the influence on blood lipid levels by baseline characteristics, multiple regression analyses were performed. Outcome lipid variables such as cholesterol were treated as continuous variables. Data, which were not normally distributed were subjected to logarithmic transformation. Potentially influencing factors, such as age, sex, waist, diagnosis of GHD etc., were categorised (see above) or treated as a continuous variable if suitable. Heterogeneity tests were performed with F-tests. Trend tests were performed with Wald tests. Linear trend tests confer to linear compartment of trend. All tests were adjusted for age at baseline and/or gender.

Longitudinal analyses were performed with repeated measurements regression. The within-patient dependency of the data was modelled by assuming unstructured variance-covariance matrixes. Comparisons of mean values at the 1 st and 2 nd year visits, versus baseline values, were performed assuming identity link and a normal distribution. Tests were performed with F-tests or Wald tests. For analyses of the proportion of patients outside a target, a logit link and a binomial distribution were used.

In the analyses of the change in cholesterol over time by baseline cholesterol category, adjustment for effects of regression to the mean was done according to the methods described by Johnson and George (38). Analyses were performed using SAS software version 8.02. Multiple regressions were run with PROC GLM.
PROC MIXED and PROC GENMOD were used for repeated measurement regression.

\section{Results}

\section{Baseline lipid profile by age and gender}

Total cholesterol. The observed overall mean total cholesterol concentration \pm s.D. was $5.9 \pm 1.3 \mathrm{mmol} / \mathrm{l}$ (Table 1). The mean increased across age categories more or less linearly, from $5.0 \mathrm{mmol} / \mathrm{l}$ in the $<20$ age category up to $6.1 \mathrm{mmol} / \mathrm{l}$ in the $40-49$ age category, thereafter no further increase was observed $(P$ for linear age-trend <0.0001; Fig. 1). Females showed a $0.2 \mathrm{mmol} / \mathrm{l}$ higher mean value than males $(95 \%$ confidence interval (CI): $0.1-0.3 ; P<0.0001)$. There was no statistically significant difference between premenopausal and post-menopausal women.

Approximately $71 \%$ of patients (95\% CI: $69 \%-73 \%$ ), $66 \%$ males and $75 \%$ females had cholesterol levels above the desired target value of $5.2 \mathrm{mmol} / \mathrm{l}$. The increase in percentage above target by age was from around $40 \%$ when $<20$ years up to around $75 \%$ when 40 years and older $(P$ for linear trend $<0.0001)$.

HDL-cholesterol. The overall mean \pm s.D. was $1.2 \pm$ $0.4 \mathrm{mmol} / \mathrm{l}$ (Table 1) and remained relatively constant over age $(P$ for heterogeneity $=0.14 ; P$ for trend $=$ 0.92). Females showed a $0.2 \mathrm{mmol} / \mathrm{l}$ higher mean value than males (95\% CI: 0.2-0.3; $P<0.0001)$. Postmenopausal women had a slightly lower mean compared to pre-menopausal women $(0.1 \mathrm{mmol} / \mathrm{l}$, $P<0.05)$.

Approximately 49\% of patients (95\% CI: 47-51\%) were below the desired target value; $46 \%$ males, $49 \%$ premenopausal females and $57 \%$ post-menopausal females.

Total cholesterol/HDL-cholesterol ratio. Due to the skewed distribution for this variable, the geometric mean was calculated, which was 4.8 (10th-90th percentile: 3.1-7.4). Similar to the mean of total cholesterol, this geometric mean increased by age in a linear fashion: from 4.1 in the $<20$ age category up to 5.0 in the 40-49 age category, after which it levelled off to 4.8 in patients of $60+$ years $(P$ for linear age-trend $<0.0001)$. Females showed a significantly lower geometric mean compared to males: $-14.1 \%(95 \%$ CI: $-16.3 \%--12.0 \%$; $P<0.0001)$. For the $40-49$ age category, this percentage of $-14.1 \%$ translates to an absolute difference of 0.77 .

Approximately $59 \%$ of the patients (95\% CI: $57 \%-$ $61 \%$ ) were above the desired target value of 4.5 . For males, the corresponding figure was $69 \%$, pre-menopausal females $44 \%$, and post-menopausal females $55 \%$ ( $P$ for heterogeneity $<0.05)$. The increase 
Table 1 Baseline description of 2589 adult GHD patients.

\begin{tabular}{|c|c|c|c|c|c|c|}
\hline & \multicolumn{3}{|c|}{ Crude statistics } & \multicolumn{3}{|c|}{ Adjusted $^{\#}$ statistics } \\
\hline & No. of non-miss. & Mean & S.D. & 10th-90th pctl & Mean & $95 \% \mathrm{Cl}$ \\
\hline \multicolumn{7}{|l|}{ Total cholesterol ( $\mathrm{mmol} / \mathrm{l})$} \\
\hline All & 2589 & 5.9 & 1.3 & $4.4-7.5$ & 6.1 & $6.0-6.2$ \\
\hline Males & 1326 & 5.8 & 1.3 & $4.3-7.5$ & 6.0 & $5.8-6.1$ \\
\hline Females & 1263 & 6.0 & 1.3 & $4.5-7.6$ & 6.2 & $6.1-6.3$ \\
\hline Pre-menopausal females & 769 & 5.9 & 1.3 & $4.4-7.6$ & 6.1 & $6.0-6.3$ \\
\hline Post-menopausal females & 494 & 6.1 & 1.3 & $4.6-7.7$ & 6.2 & $6.1-6.4$ \\
\hline \multicolumn{7}{|l|}{ HDL-cholesterol $(\mathrm{mmol} / \mathrm{l})$} \\
\hline All & 2587 & 1.2 & 0.4 & $0.8-1.7$ & 1.2 & $1.2-1.3$ \\
\hline Males & 1325 & 1.1 & 0.3 & $0.8-1.6$ & 1.1 & $1.1-1.1$ \\
\hline Females & 1262 & 1.4 & 0.4 & $0.9-1.9$ & 1.4 & $1.3-1.4$ \\
\hline Pre-menopausal females & 769 & 1.4 & 0.4 & $0.9-1.9$ & 1.4 & $1.3-1.4$ \\
\hline Post-menopausal females & 493 & 1.3 & 0.4 & $0.9-1.8$ & 1.3 & $1.3-1.4$ \\
\hline \multicolumn{7}{|l|}{ LDL-cholesterol (mmol/I) } \\
\hline All & 2435 & 3.7 & 1.1 & $2.4-5.3$ & 3.9 & $3.8-3.9$ \\
\hline Males & 1226 & 3.7 & 1.1 & $2.4-5.2$ & 3.8 & $3.7-3.9$ \\
\hline Females & 1209 & 3.7 & 1.1 & $2.4-5.3$ & 3.9 & $3.8-4.0$ \\
\hline Pre-menopausal females & 740 & 3.7 & 1.1 & $2.4-5.1$ & 3.9 & $3.7-4.0$ \\
\hline Post-menopausal females & 469 & 3.8 & 1.1 & $2.5-5.4$ & 3.9 & $3.8-4.1$ \\
\hline \multicolumn{7}{|l|}{ Triglycerides ${ }^{\star}(\mathrm{mmol} / \mathrm{l})$} \\
\hline All & 2589 & 1.8 & $e^{0.582}$ & $0.9-3.8$ & 1.9 & $1.9-2.0$ \\
\hline Male & 1326 & 1.9 & $e^{0.604}$ & $0.8-4.1$ & 2.0 & $1.9-2.1$ \\
\hline Females & 1263 & 1.8 & $e^{0.554}$ & $0.9-3.5$ & 1.9 & $1.8-2.0$ \\
\hline Pre-menopausal females & 769 & 1.7 & $e^{0.565}$ & $0.8-3.3$ & 1.8 & $1.7-1.9$ \\
\hline Post-menopausal females & 494 & 1.9 & $e^{0.519}$ & $1.0-3.7$ & 2.0 & $1.9-2.1$ \\
\hline BMI $\left(\mathrm{kg} / \mathrm{m}^{2}\right)$ & 2527 & 28.2 & 5.7 & $21.7-35.7$ & 28.2 & $28.0-28.5$ \\
\hline Waist/hip ratio & 2353 & 0.92 & 0.10 & $0.80-1.03$ & 0.92 & $0.91-0.92$ \\
\hline Waist (cm) & 2358 & 95.3 & 14.6 & $77-115$ & 95.2 & $94.7-95.8$ \\
\hline Fat tissue $^{\star}, \mathrm{BIA}(\mathrm{kg})$ & 1054 & 23.8 & $e^{0.445}$ & $14.1-42.0$ & 23.9 & $23.3-24.5$ \\
\hline Lean Tissue ${ }^{\star}$, BIA (kg) & 1054 & 51.8 & $\mathrm{e}^{0.293}$ & $37.4-71.5$ & 51.5 & $50.8-52.2$ \\
\hline Fat tissue*, DXA $(\mathrm{kg})$ & 451 & 25.6 & $\mathrm{e}^{0.419}$ & $15.0-42.8$ & 25.7 & $24.8-26.7$ \\
\hline Lean tissue*, DXA (kg) & 451 & 45.5 & $e^{0.270}$ & $32.3-64.8$ & 45.5 & $44.5-46.2$ \\
\hline Blood pressure, diastolic & 2519 & 79 & 11 & $65-90$ & 79 & 79-79 \\
\hline Blood pressure, systolic & 2519 & 127 & 19 & $105-150$ & 127 & $126-128$ \\
\hline
\end{tabular}

\# Adjusted to 40-49 year age group. *For triglycerides, fat and lean tissue geometric means are presented. The s.D. is given as 'e' to the power of the S.D. at logarithmic scale, i.e. for triglycerides, all patients, using the percentiles of the normal distribution, approximately $95 \%$ of the observations should be in the range $1.81 / \mathrm{e}^{1.96^{*} 0.582}$ to $1.81^{*} \mathrm{e}^{1.96^{*} 0.582}=0.58-5.66 \mathrm{mmol} / \mathrm{l}$.

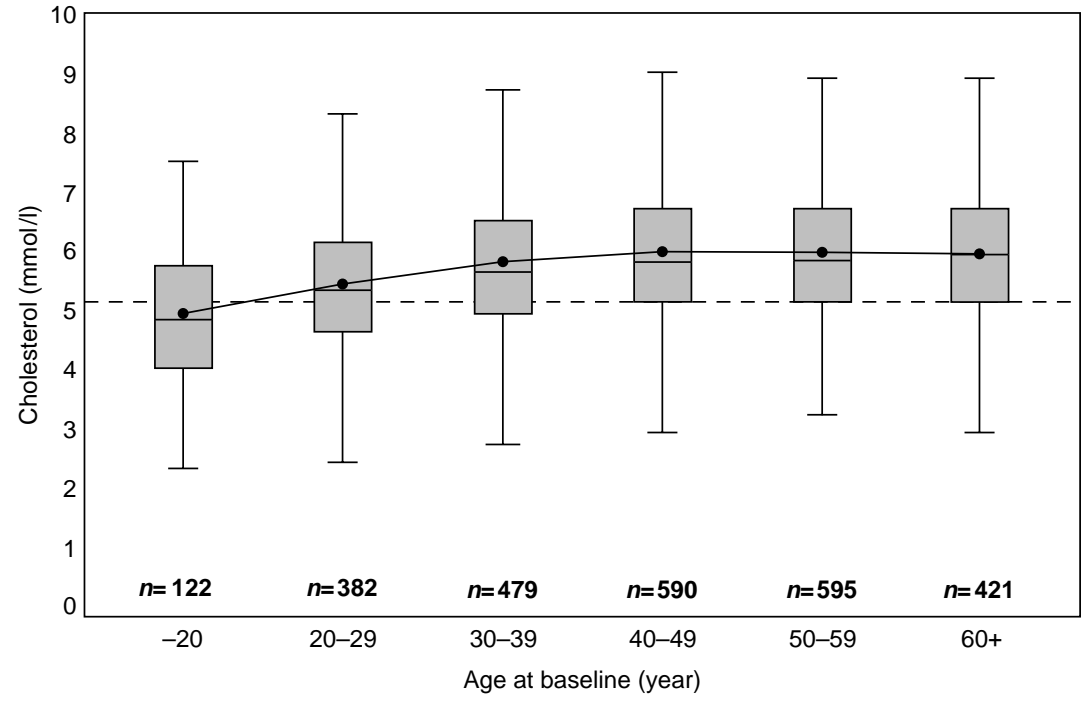

Figure 1 Total cholesterol baseline concentrations in 2589 GHD patients by age groups. Median, 10-25-75-90 percentile. The solid line represents the mean trend. The dashed line represents the target value of $5.2 \mathrm{mmol} / \mathrm{l}$. 
in percentage above target by age category was quite steady but levelled off successively: <20 year, 37\%; 20-29 year, 49\%; 30-39 year, 58\%; 40-49 year, $62 \%$; 50-59 year, $66 \%$ and $60+$ year, $63 \%$ ( $P$ for linear trend $<0.0001)$.

LDL-cholesterol. The overall mean \pm s.D. was $3.7 \pm$ $1.1 \mathrm{mmol} / \mathrm{l}$, following the same pattern as for total cholesterol (Table 1).

Triglycerides. The geometric mean for the overall cohort was $1.8 \mathrm{mmol} / \mathrm{l}$ (10th-90th percentile: 0.9-3.8; Table 1). The linear increase by age was significant $(P<0.0001)$ but levelled off in a similar fashion to the other lipid variables.

Approximately $57 \%$ of males, $49 \%$ of pre-menopausal females and $60 \%$ of post-menopausal females had higher values than the target.

\section{Multiple regression models for baseline lipids with adjustment for age and gender}

Total cholesterol. Of the variables examined besides age and gender, the onset of GHD, duration of GHD, severity of hypopituitarism, severity of GHD, aetiology, radiotherapy, BMI, WHR and waist circumference did not statistically significantly influence the baseline cholesterol concentration. The following variables were found to have an effect:

- smoking: the mean concentration was $0.2 \mathrm{mmol} / \mathrm{l}$ higher in smokers $(n=468)$ compared to nonsmokers (95\% CI: 0.0-0.3; $P=0.008$ ).

- epilepsy: the mean concentration was $0.4 \mathrm{mmol} / \mathrm{l}$ higher in patients receiving anti-epileptic drugs $(n=128)$ compared to patients without epilepsy (95\% CI: 0.2-0.6; $P<0.0001$ ).

- diabetes mellitus: the mean concentration was $0.3 \mathrm{mmol} / \mathrm{l}$ lower in patients with diabetes mellitus $(n=118)$ compared to non-diabetic patients $(95 \%$ CI: $-0.5-0.0 ; P=0.027)$.

- hyperlipidaemia: the mean concentration was $0.2 \mathrm{mmol} / \mathrm{l}$ higher in patients taking lipid-lowering drugs $(n=182)$ compared to patients without lipidlowering drugs (95\% CI: $-0.5--0.0 ; P=0.05)$.

There was no significant association between baseline total cholesterol level and IGF-I SDS ( $P$ for linear trend $=0.19 ; P$ for heterogeneity $=0.68)$. LDL-cholesterol showed similar trends as that of total cholesterol.

HDL-cholesterol. Three variables showed a statistically significant, decreasing linear trend for HDL-cholesterol concentrations. As the HDL-cholesterol concentrations were independent of age, the presented mean values are applicable for all ages.

- BMI: mean HDL-cholesterol concentrations decreased with increasing BMI category: $<20 \mathrm{~kg} / \mathrm{m}^{2}$, $1.6 \mathrm{mmol} / \mathrm{l} ; 20-24 \mathrm{~kg} / \mathrm{m}^{2}, 1.4 \mathrm{mmol} / \mathrm{l} ; 25-29 \mathrm{~kg} / \mathrm{m}^{2}$, $1.2 \mathrm{mmol} / \mathrm{l}$; $30-34 \mathrm{~kg} / \mathrm{m}^{2}, \quad 1.1 \mathrm{mmol} / \mathrm{l}$; and $>35 \mathrm{~kg} / \mathrm{m}^{2} ; 1.1 \mathrm{mmol} / \mathrm{l}$ ( $P$ for trend $\left.<0.0001\right)$.

- WHR: mean HDL-cholesterol concentrations decreased with increasing WHR category: <0.85, $1.3 \mathrm{mmol} / \mathrm{l}$; 0.85-0.91, $1.3 \mathrm{mmol} / \mathrm{l} ; 0.91-0.97,1.2 \mathrm{mmol} / \mathrm{l}$; $>0.97,1.1 \mathrm{mmol} / \mathrm{l}$ ( $P$ for trend $<0.0001)$.

- waist circumference: mean HDL-cholesterol concentrations decreased with increasing waist category in males: $<92 \mathrm{~cm}, \quad 1.3 \mathrm{mmol} / \mathrm{l}$; 92-102 cm, $1.1 \mathrm{mmol} / \mathrm{l}$; > $102 \mathrm{~cm}, 1.0 \mathrm{mmol} / \mathrm{l}$; and in females: $<80 \mathrm{~cm}, \quad 1.5 \mathrm{mmol} / \mathrm{l} ; 80-88 \mathrm{~cm}$, $1.4 \mathrm{mmol} / \mathrm{l}$; $>88 \mathrm{~cm}, 1.3 \mathrm{mmol} / \mathrm{l}$. Both trends were highly significant $(P<0.0001)$.

Other variables associated with a significantly lower mean HDL-cholesterol concentration $(-0.1 \mathrm{mmol} / \mathrm{l})$ were smoking, lipid-lowering drugs and diabetes mellitus $(P<0.01)$.

\section{Triglycerides}

- BMI, WHR and waist circumference showed statistically significant influences on mean levels. There was a consistent linear trend with 3\% increase in triglycerides concentration per BMI category $(95 \%$ CI: $2.6 \%-3.4 \% ; P<0.0001)$. Triglycerides increased by $1.3 \%$ per $\mathrm{cm}$ waist in males and females combined (95\% CI: $1.0-1.6 ; P<0.0001)$ and for WHR the trend estimate was approximately $1.1 \%$ per 0.01 of ratio (95\% CI: $0.9 \%-1.3 \% ; P<0.0001$ ).

Patients with craniopharyngioma showed 50\% higher geometric mean triglycerides compared to patients with idiopathic GHD (95\% CI: 37\%-65\%; P<0.0001). The other aetiological groups showed between 16 and $23 \%$ higher values than idiopathic GHD $(<0.0001<P<$ $0.03)$. Patients with childhood onset of the disease had $8 \%$ lower values, smokers $10 \%$ higher values, patients taking lipid-lowering drugs 23\% higher values; patients taking anti-epileptic drugs 13\% higher values, and diabetic patients $24 \%$ higher values $(P<0.02$ in all cases).

\section{BMI, WHR, blood pressure and body composition at baseline}

Baseline data regarding BMI, WHR, waist circumference, blood pressure and body composition are given in Table 1. 
Obesity was prominent, as 806 of 2527 patients $(32 \%)$ had a BMI $>30 \mathrm{~kg} / \mathrm{m}^{2}$, while 98 patients $(4 \%)$ had a BMI $<20 \mathrm{~kg} / \mathrm{m}^{2}$. BMI increased with age, WHR and waist circumference (data not shown). It was higher in post-menopausal females than in males, in adult-onset GHD than in childhood-onset GHD, in patients with craniopharyngioma than in patients with other aetiology, in patients who had cranial irradiation, in patients with multiple pituitary deficiencies, in smokers, in patients with diabetes mellitus, and in patients taking anti-epileptic or lipidlowering drugs. Fat mass measured by BIA or DXA demonstrated largely similar associations (data not shown).

Waist circumference was above the target value in $46 \%$ of patients, $40 \%$ of males, $56 \%$ of females, $51 \%$ of pre-menopausal females, and $64 \%$ of post-menopausal females. Fifteen percent of patients had a medical history of hypertension. Blood pressure was above the target value in $26 \%$ of patients, $28 \%$ of men, $23 \%$ of females, $20 \%$ of pre-menopausal females, and $28 \%$ of post-menopausal females. Blood pressure correlated with age, severity of GHD, WHR, waist, and smoking, while systolic blood pressure correlated additionally with lipid-lowering drugs and presence of diabetes mellitus (data not shown). BMI, waist circumference and blood pressure showed a significantly positive correlation to IGF-I SDS.

\section{Change in lipid profile during GH replacement}

Total cholesterol. Statistically significant reductions in total cholesterol were observed after both 1 year and 2 years of GH replacement therapy: $-0.4 \mathrm{mmol} / \mathrm{l}(95 \% \mathrm{CI}$ : $-0.4--0.3 ; P<0.0001)$ and $-0.5 \mathrm{mmol} / \mathrm{l}(95 \% \mathrm{CI}$ : $-0.5--0.4 ; P<0.0001$ ), respectively (Table 2 ). The additive effect during the second year of treatment was small, $-0.1 \mathrm{mmol} / \mathrm{l}$, but still significant compared to the first year $(95 \% \mathrm{CI}-0.15--0.04 ; P=0.001)$. Moreover, assuming a constant proportional change, the higher the baseline value, the larger the absolute decrease in cholesterol, even after adjustment for regression to the mean: $\Delta(\mathrm{mmol} / \mathrm{l}) /(\mathrm{mmol} / \mathrm{l}$ at baseline $)=-0.06$ $(P=0.01)$. This relationship would predict that a patient with a hypothetical baseline value of $7.5 \mathrm{mmol} / \mathrm{l}$ would demonstrate a change in cholesterol of $7.5 \times(-$ $0.06)=-0.45 \mathrm{mmol} / \mathrm{l}$ after 1 year of treatment. After 2 years of treatment, these observations were strengthened in all subgroups $(P<0.0001)$. The proportional effect per $\mathrm{mmol} / \mathrm{l}$ at baseline was increased to -0.11 $(P=0.0006)$.

Table 2 Lipid concentrations at baseline (BL) and after GH replacement therapy for the subset of 1206 patients with 2 years of follow-up.

\begin{tabular}{|c|c|c|c|c|c|c|c|c|c|c|}
\hline & \multicolumn{4}{|c|}{ Mean* values $(\mathrm{mmol} / \mathrm{l})$ at } & \multicolumn{3}{|c|}{$95 \% \mathrm{Cl}$ for change $(\mathrm{mmol} / \mathrm{l})$} & \multicolumn{3}{|c|}{ P-values $\left(\mathrm{H}_{0}:\right.$ No change) } \\
\hline & $\mathrm{BL}$ & $1 \mathrm{yr}$ & $2 \mathrm{yr}$ & S.E.M & $\mathrm{BL}-1 \mathrm{yr}$ & $\mathrm{BL}-2 \mathrm{yr}$ & $1 \mathrm{yr}-2 \mathrm{yr}$ & $\mathrm{BL}-1 \mathrm{yr}$ & $\mathrm{BL}-2 \mathrm{yr}$ & $1 y r-2 y r$ \\
\hline \multicolumn{11}{|l|}{ Total cholesterol $(\mathrm{mmol} / \mathrm{l})$} \\
\hline All & 5.9 & 5.5 & 5.5 & 0.035 & $-0.4--0.3$ & $-0.5--0.4$ & $-0.2--0.0$ & $<.0001$ & $<.0001$ & 0.001 \\
\hline Males & 5.8 & 5.4 & 5.3 & 0.048 & $-0.5--0.4$ & $-0.6--0.4$ & $-0.2--0.0$ & $<.0001$ & $<.0001$ & 0.023 \\
\hline Pre-menopausal females & 6.0 & 5.7 & 5.7 & 0.060 & $-0.4--0.2$ & $-0.4--0.2$ & $-0.1-0.1$ & $<.0001$ & $<.0001$ & 0.72 \\
\hline Post-menopausal females & 6.2 & 5.8 & 5.6 & 0.10 & $-0.5--0.2$ & $-0.8--0.5$ & $-0.4--0.1$ & $<.0001$ & $<.0001$ & 0.0009 \\
\hline \multicolumn{11}{|l|}{ HDL-cholesterol $(\mathrm{mmol} / \mathrm{l})$} \\
\hline All & 1.3 & 1.3 & 1.2 & 0.011 & $-0.0--0.0$ & $-0.1--0.0$ & $-0.0--0.0$ & 0.002 & $<.0001$ & 0.03 \\
\hline Males & 1.2 & 1.2 & 1.1 & 0.014 & $-0.0-0.0$ & $-0.1--0.0$ & $-0.1--0.0$ & 0.41 & 0.001 & 0.003 \\
\hline Pre-menopausal females & 1.4 & 1.4 & 1.4 & 0.020 & $-0.1-0.0$ & $-0.1-0.0$ & $-0.0-0.0$ & 0.08 & 0.06 & 0.65 \\
\hline Post-menopausal females & 1.4 & 1.3 & 1.3 & 0.027 & $-0.11--0.0$ & $-0.1--0.0$ & $-0.0-0.0$ & 0.001 & 0.0006 & 0.90 \\
\hline \multicolumn{11}{|l|}{ Total/HDL-cholesterol* } \\
\hline All & 4.8 & 4.5 & 4.5 & 0.045 & $-0.3--0.2$ & $-0.3--0.2$ & $-0.1-0.1$ & $<.0001$ & $<.0001$ & 0.90 \\
\hline Males & 5.1 & 4.8 & 4.8 & 0.068 & $-0.4--0.3$ & $-0.4--0.2$ & $-0.0-0.1$ & $<.0001$ & $<.0001$ & 0.21 \\
\hline Pre-menopausal females & 4.4 & 4.2 & 4.2 & 0.07 & $-0.3--0.1$ & $-0.3--0.0$ & $-0.1-0.1$ & 0.001 & 0.009 & 0.53 \\
\hline Post-menopausal females & 4.6 & 4.5 & 4.4 & 0.10 & $-0.2-0.1$ & $-0.4--0.1$ & $-0.3--0.0$ & 0.43 & 0.007 & 0.018 \\
\hline \multicolumn{11}{|l|}{ LDL-cholesterol ( $\mathrm{mmol} / \mathrm{l})$} \\
\hline All & 3.8 & 3.4 & 3.4 & 0.031 & $-0.4--0.3$ & $-0.5--0.4$ & $-0.1--0.0$ & $<.0001$ & $<.0001$ & 0.0005 \\
\hline Males & 3.7 & 3.4 & 3.3 & 0.045 & $-0.4--0.3$ & $-0.5--0.4$ & $-0.2--0.0$ & $<.0001$ & $<.0001$ & 0.01 \\
\hline Pre-menopausal females & 3.7 & 3.5 & 3.4 & 0.052 & $-0.4--0.2$ & $-0.4--0.2$ & $-0.1-0.1$ & $<.0001$ & $<.0001$ & 0.70 \\
\hline Post-menopausal females & 4.0 & 3.6 & 3.4 & 0.080 & $-0.5--0.2$ & $-0.7--0.4$ & $-0.4--0.1$ & $<.0001$ & $<.0001$ & 0.001 \\
\hline \multicolumn{11}{|l|}{ Triglycerides* (mmol/l) } \\
\hline All & 1.7 & 1.7 & 1.7 & 0.028 & $-0.1-0.0$ & $-0.1-0.1$ & $-0.0-0.1$ & 0.54 & 0.95 & 0.58 \\
\hline Males & 1.7 & 1.7 & 1.7 & 0.043 & $-0.1-0.0$ & $-0.1-0.0$ & $-0.1-0.1$ & 0.06 & 0.18 & 0.64 \\
\hline Pre-menopausal females & 1.6 & 1.7 & 1.7 & 0.045 & $-0.0-0.1$ & $-0.0-0.2$ & $-0.1-0.1$ & 0.14 & 0.055 & 0.61 \\
\hline Post-menopausal females & 1.8 & 1.8 & 1.8 & 0.043 & $-0.1-0.1$ & $-0.1-0.1$ & $-0.1-0.1$ & 0.96 & 0.86 & 0.83 \\
\hline
\end{tabular}

${ }^{*}$ S.E.M. $=$ Standard error of mean. Valid for use to compute confidence intervals at all visits (BL, $1 \mathrm{yr}$ and $2 \mathrm{yr}$, respectively). For Total/HDL-cholesterol and triglycerides, geometric means are presented and S.E.M. corresponds to $1 / 4$ of $95 \%$ confidence interval length. Due to a large number, these confidence intervals are symmetrical. 
Table 3 Percentage of patients outside target range for the subset of 1206 patients with 2 years of follow-up.

\begin{tabular}{|c|c|c|c|c|c|c|c|}
\hline \multirow[b]{3}{*}{ Lipid } & \multirow{3}{*}{$\begin{array}{c}\text { Target range } \\
(\mathrm{mmol} / \mathrm{l})\end{array}$} & \multicolumn{6}{|c|}{ Patients outside target range } \\
\hline & & \multicolumn{3}{|c|}{ Proportion \pm S.E.M.(in \%) } & \multicolumn{3}{|c|}{$P$-values $\left(\mathrm{H}_{0}\right.$ : No 'true' change $)$} \\
\hline & & $\mathrm{BL}$ & $1 \mathrm{yr}$ & $2 y r$ & $\mathrm{BL}-1 \mathrm{yr}$ & $\mathrm{BL}-2 \mathrm{yr}$ & $1 \mathrm{yr}-2 \mathrm{yr}$ \\
\hline \multicolumn{8}{|l|}{ Total cholesterol $(\mathrm{mmol} / \mathrm{l})$} \\
\hline All & $<5.2$ & $73 \pm 1$ & $62 \pm 2$ & $60 \pm 2$ & $<.0001$ & $<.0001$ & 0.28 \\
\hline Males & « & $68 \pm 2$ & $57 \pm 2$ & $54 \pm 2$ & $<.0001$ & $<.0001$ & 0.28 \\
\hline Pre-menopausal females & « & $77 \pm 2$ & $63 \pm 3$ & $65 \pm 3$ & $<.0001$ & $<.0001$ & 0.52 \\
\hline Post-menopausal females & « & $82 \pm 3$ & $72 \pm 3$ & $66 \pm 4$ & 0.002 & $<.0001$ & 0.10 \\
\hline \multicolumn{8}{|l|}{ HDL-cholesterol $(\mathrm{mmol} / \mathrm{ll})$} \\
\hline All & $>1.0 />1.3$ & $46 \pm 1$ & $50 \pm 2$ & $51 \pm 2$ & 0.043 & 0.0009 & 0.47 \\
\hline Males & $>1.0$ & $42 \pm 2$ & $44 \pm 2$ & $48 \pm 2$ & 0.24 & 0.007 & 0.08 \\
\hline Pre-menopausal females & $>1.3$ & $48 \pm 3$ & $52 \pm 3$ & $51 \pm 3$ & 0.12 & 0.37 & 0.55 \\
\hline Post-menopausal females & $>1.3$ & $52 \pm 4$ & $61 \pm 4$ & $60 \pm 4$ & 0.009 & 0.03 & 0.73 \\
\hline \multicolumn{8}{|l|}{ Total/HDL-cholesterol ratio } \\
\hline All & $<4.5$ & $57 \pm 1$ & $51 \pm 2$ & $50 \pm 2$ & $<.0001$ & $<.0001$ & 0.29 \\
\hline Males & $\ll$ & $66 \pm 2$ & $60 \pm 2$ & $60 \pm 2$ & 0.0003 & 0.0002 & 0.80 \\
\hline Pre-menopausal females & « & $45 \pm 3$ & $39 \pm 3$ & $40 \pm 3$ & 0.02 & 0.05 & 0.68 \\
\hline Post-menopausal females & « & $54 \pm 4$ & $52 \pm 4$ & $40 \pm 4$ & 0.63 & 0.0004 & 0.002 \\
\hline \multicolumn{8}{|l|}{ LDL-cholesterol (mmol/l) } \\
\hline All & $<3.4$ & $62 \pm 1$ & $50 \pm 2$ & $47 \pm 2$ & $<.0001$ & $<.0001$ & 0.06 \\
\hline Males & $\ll$ & $60 \pm 2$ & $48 \pm 2$ & $44 \pm 2$ & $<.0001$ & $<.0001$ & 0.07 \\
\hline Pre-menopausal females & « & $63 \pm 3$ & $49 \pm 3$ & $49 \pm 3$ & $<.0001$ & $<.0001$ & 0.78 \\
\hline Post-menopausal females & « & $68 \pm 3$ & $56 \pm 4$ & $49 \pm 4$ & 0.0004 & $<.0001$ & 0.08 \\
\hline \multicolumn{8}{|l|}{ Triglycerides $(\mathrm{mmol} / \mathrm{l})$} \\
\hline All & $<1.7$ & $50 \pm 1$ & $48 \pm 2$ & $50 \pm 2$ & 0.19 & 0.87 & 0.16 \\
\hline Males & « & $51 \pm 2$ & $46 \pm 2$ & $49 \pm 2$ & 0.02 & 0.42 & 0.17 \\
\hline Pre-menopausal females & « & $46 \pm 3$ & $49 \pm 3$ & $51 \pm 3$ & 0.35 & 0.09 & 0.44 \\
\hline Post-menopausal females & « & $55 \pm 4$ & $53 \pm 4$ & $53 \pm 4$ & 0.64 & 0.48 & 0.80 \\
\hline \multicolumn{8}{|l|}{ Blood pressure $(\mathrm{mmHg})$} \\
\hline All & $<130 / 85$ & $26 \pm 1$ & $22 \pm 1$ & $23 \pm 1$ & 0.004 & 0.01 & 0.78 \\
\hline Males & « & $29 \pm 2$ & $25 \pm 2$ & $23 \pm 2$ & 0.02 & 0.002 & 0.35 \\
\hline Pre-menopausal females & « & $20 \pm 2$ & $18 \pm 2$ & $21 \pm 2$ & 0.23 & 0.92 & 0.22 \\
\hline Post-menopausal females & « & $28 \pm 3$ & $24 \pm 3$ & $26 \pm 3$ & 0.28 & 0.51 & 0.64 \\
\hline \multicolumn{8}{|l|}{ Waist circumference $(\mathrm{cm})$} \\
\hline All & $<102 /<88$ & $45 \pm 2$ & $42 \pm 2$ & $43 \pm 2$ & 0.0002 & 0.02 & 0.27 \\
\hline Males & $<102$ & $35 \pm 2$ & $32 \pm 2$ & $33 \pm 2$ & 0.02 & 0.14 & 0.54 \\
\hline Pre-menopausal females & $<88$ & $52 \pm 3$ & $46 \pm 3$ & $47 \pm 3$ & 0.001 & 0.01 & 0.58 \\
\hline Post-menopausal females & $«$ & $63 \pm 4$ & $61 \pm 4$ & $64 \pm 4$ & 0.58 & 0.78 & 0.37 \\
\hline
\end{tabular}

The change in total cholesterol concentration during GH replacement therapy was essentially unaffected by any of the other variables examined. GH replacement also induced a decrease in total cholesterol in patients taking lipid-lowering drugs. In all categories, total cholesterol concentration was significantly reduced after both 1 and 2 years.

A highly significant decrease in the percentage of patients with values exceeding target value was observed after both 1 and 2 years of treatment (Table 3).

Descriptive model for change in total cholesterol by age and gender. A descriptive model for mean total cholesterol by age, gender and visit (baseline, 1 year, 2 years) was also fitted. This model indicates that improvement in total cholesterol concentrations was largest during the first year of treatment and was greater, the older the patients were at the start of the treatment. During the second year of treatment, the improvement was smaller and indeed absent in younger ages. Females had in average, $0.3 \mathrm{mmol} / \mathrm{l}$ higher mean cholesterol values than males (95\% CI: 0.2-0.4). Otherwise, males and females showed the same pattern of change (Fig. 2).

The model fit was as follows: mean cholesterol $=$ $5.93+0.32 \mathrm{G}-0.53 \mathrm{~V}+0.14 \mathrm{~V}^{2}-0.0012(\mathrm{~A}-45)-$ $0.0014(\mathrm{~A}-45)^{2}+0.0015_{\mathrm{I}}(\mathrm{A}-50)^{2}-0.003 \mathrm{~V}(\mathrm{~A}-45)$, where $\mathrm{G}=$ gender $(0=$ male, $\quad 1=$ female $) ; \mathrm{V}=$ visit $(0,1,2), A=$ age (centred to 45 years), ${ }_{\mathrm{I}}(\mathrm{A}-50)$ an index variable which is 0 if $A<50$, and $A-50$ when $A \geq 50$. The corresponding standard error estimate for each parameter was $(0.045)-(0.059)-(0.047)-(0.023)-$ $(0.0069)-(0.00033)-(0.00065)-(0.0010)$, respectively. The interaction test between gender and visit $(G V)$ was not significant $(P=0.22)$ and the term was not included in the model. The model was fitted assuming the same age pattern for both genders.

Other lipid parameters. Mean HDL-cholesterol changed from $1.3 \mathrm{mmol} / \mathrm{l}$ to $1.2 \mathrm{mmol} / \mathrm{l}$ after 2 years of treatment (Table 2). Although this change was minimal, it was statistically significant. The percentage 
A Cholesterol $(\mathrm{mmol} / \mathrm{l})$

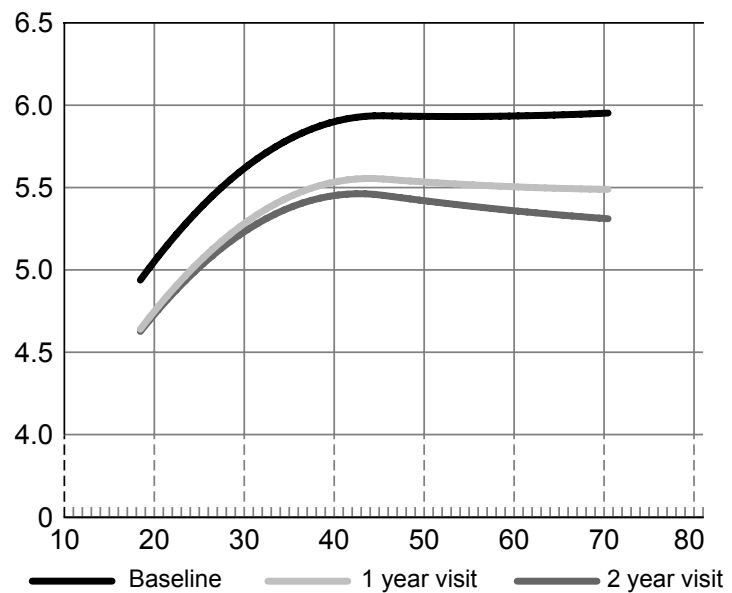

B Cholesterol $(\mathrm{mmol} / \mathrm{l})$

Females

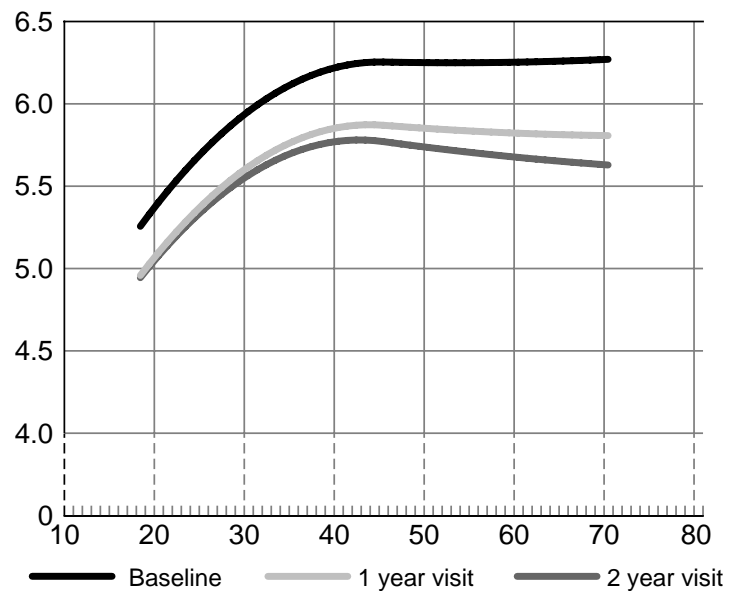

Figure 2 Mean total cholesterol concentration by age and gender at baseline, and after 1 year and 2 years of $\mathrm{GH}$ replacement for the subset of 1206 GHD patients with 2 year longitudinal follow-up. of patients with a value above target increased significantly (Table 3).

The geometric mean of total cholesterol over HDLcholesterol ratio decreased significantly over the 2-year treatment period from 4.8 to $4.5(P<0.0001)$. The decrease was significant in both males and females (Table 2). The percentage of patients with a ratio exceeding the target value also decreased significantly during the treatment period (Table 3 ).

The major change in total mean cholesterol is accounted for by the change in mean LDL-cholesterol, which was $-0.3 \mathrm{mmol} / \mathrm{l}$ after 1 year and $-0.4 \mathrm{mmol} / \mathrm{l}$ after 2 years (Table 2 ). A highly significant decrease in the percentage of patients with values exceeding the target was observed after both 1 and 2 years of treatment (Table 3).

No statistically significant changes in geometric mean triglycerides were observed after 1 and 2 years of GH therapy, respectively (Table 2 and Table 3).

\section{Changes in BMI, blood pressure, WHR and body composition during GH replacement}

$\mathrm{GH}$ replacement therapy did not induce significant changes in BMI or blood pressure after 1 and 2 years of GH treatment (Table 4).

There was a significant reduction in WHR, waist circumference, and fat tissue both by DXA and BIA with a corresponding increase in lean body mass (also both by DXA and BIA) (Table 4). The changes were related with a significant trend to aetiology of pituitary diagnosis, year of GHD and BMI, but not to any of the other tested co-variables (data not shown).

There was a significant decrease in the percentage of patients with blood pressure and waist circumference exceeding the target value during the treatment period (Table 3).

Table 4 Mean values at baseline (BL) and after GH replacement therapy for the subset of 1206 patients with 2 years of follow-up.

\begin{tabular}{|c|c|c|c|c|c|c|c|c|c|c|}
\hline & \multicolumn{4}{|c|}{ Mean $^{*}$ values at } & \multicolumn{3}{|c|}{$95 \% \mathrm{Cl}$ for mean change } & \multicolumn{3}{|c|}{$P$-values } \\
\hline & $B L$ & $1 \mathrm{yr}$ & $2 \mathrm{yr}$ & S.E.M. ${ }^{*}$ & $\mathrm{BL}-1 \mathrm{yr}$ & $\mathrm{BL}-2 \mathrm{yr}$ & $1-2 \mathrm{yr}$ & $\mathrm{BL}-1 \mathrm{yr}$ & $\mathrm{BL}-2 \mathrm{yr}$ & $1 \mathrm{yr}-2 \mathrm{yr}$ \\
\hline $\mathrm{BMI}\left(\mathrm{kg} / \mathrm{m}^{2}\right)$ & 27.9 & 28.0 & 28.2 & 0.017 & $-0.0--0.2$ & $0.2-0.4$ & $0.2-0.4$ & 0.25 & $<.0001$ & $<.0001$ \\
\hline Waist/hip ratio & 0.91 & 0.90 & 0.90 & 0.002 & $-0.02--0.01$ & $-0.01--0.01$ & $-0.0-0.0$ & $<.0001$ & $<.0001$ & 0.79 \\
\hline Waist (cm) & 94.6 & 93.0 & 93.6 & 0.42 & $-1.9--1.3$ & $-1.4--0.7$ & $0.2-0.9$ & $<.0001$ & $<.0001$ & 0.0005 \\
\hline Fat mass* $(\mathrm{kg})(\mathrm{BIA})(n=493)$ & 23.0 & 21.8 & 22.4 & 0.44 & $-1.8--0.7$ & $-1.3--0.0$ & $0.1-1.1$ & $<.0001$ & 0.05 & 0.01 \\
\hline Lean mass* $(\mathrm{kg})(\mathrm{BIA})(n=493)$ & 51.2 & 52.5 & 52.5 & 0.56 & $0.7-1.9$ & $0.9-1.9$ & $-0.5-0.6$ & $<.0001$ & $<.0001$ & 0.77 \\
\hline Fat mass ${ }^{\star}(\mathrm{kg})(\mathrm{DXA})(n=261)$ & 26.0 & 23.9 & 23.8 & 0.59 & $-2.8--1.5$ & $-2.9--1.5$ & $-0.5-0.4$ & $<.0001$ & $<.0001$ & 0.74 \\
\hline Lean mass ${ }^{\star}(\mathrm{kg})(\mathrm{DXA})(n=261)$ & 45.7 & 47.4 & 47.9 & 0.68 & $1.3-2.2$ & $1.6-2.8$ & $0.1-0.8$ & $<.0001$ & $<.0001$ & 0.018 \\
\hline Blood pressure, diastolic $(\mathrm{mmHg})$ & 79 & 79 & 79 & 0.32 & $-1-0$ & $-1-0$ & $-1-1$ & 0.09 & 0.11 & 0.92 \\
\hline Blood pressure, systolic $(\mathrm{mmHg})$ & 127 & 126 & 127 & 0.52 & $-1-0$ & $-1-1$ & $-0-1$ & 0.25 & 0.86 & 0.31 \\
\hline
\end{tabular}

"S.E.M. = Standard error of mean. Valid for use to compute confidence intervals at all visits (BL, $1 \mathrm{yr}$ and $2 \mathrm{yr}$, respectively). For fat and lean tissue mass, respectively, geometric means are presented and S.E.M. corresponds to $1 / 4$ of $95 \%$ confidence interval length. Due to a large number, these confidence intervals are symmetrical. 


\section{Discussion}

The results of this analysis confirm previous observations showing that adults with GHD have an adverse cardiovascular risk profile. The main discriminative findings at baseline were dyslipidaemia, elevated BMI, incidence of hypertension, unfavourable WHR and body composition. These adverse parameters can to some extent explain the increased cardiovascular mortality of GHD adults. The analysis of the effect of GH replacement corroborates with previous studies, showing an improvement in lipid profile and body composition. The distinguishing features of this analysis are that it involved a large number of patients, that lipid concentrations were measured in a single central laboratory, and that the effects of $\mathrm{GH}$ replacement therapy were studied over a relatively long period of time.

The lipid data are in agreement with previous observations showing that GHD adults have an adverse lipid profile; $(12,25,26,31,39,40)$. The dyslipidaemia seen at baseline in this analysis was characterised by increased concentrations of total cholesterol and LDLcholesterol and normal concentrations of HDL-cholesterol and triglycerides. An identical pattern has been observed before in adults with GHD (26), while other researchers have reported decreased concentration of HDL-cholesterol and increased concentration of triglycerides $(25,39)$.

Our investigation on the effects of a range of potentially influential variables on the baseline lipid profile suggests that hypercholesterolaemia is most marked in elderly patients, women, smokers and patients taking anti-epileptic medication. The effects observed for age and smoking are not surprising, as these variables are known to increase the risk of hypercholesterolaemia in the general population. The increased baseline concentration of total cholesterol in patients with epilepsy is probably linked to their antiepileptic medication (41). Our finding that cholesterol concentrations tend to be higher in GHD women than in GHD men is consistent with previous data showing that the risk of premature death from cardiovascular disease is elevated to a greater degree in women with conventionally treated hypopituitarism than in men with this condition $(1,3)$. However, the details of our findings for men and women contrast with results reported before, showing that the main lipid abnormality in women was a decreased concentration of HDLcholesterol $(12,42)$. In the present study, the main abnormality in women was an increase in total cholesterol. Our observation that patients with adultonset GHD had a concentration of total cholesterol comparable to those with childhood-onset GHD is consistent with the data described before, showing that patients with these conditions differ in many respects but not in cholesterol metabolism (43).
The present analysis has confirmed the adverse profile of both blood pressure and body composition in GHD patients at baseline. Thus $26 \%$ of GHD patients, including $15 \%$ on anti-hypertensive drugs, had a blood pressure above the target value of $135 / 85$ in keeping with a previous demonstration of GHD patients having a changed circadian blood pressure pattern with more than 30\% non-dippers (44).

BMI was adversely affected by adult onset of the disease, anti-epileptic drugs, previous radiotherapy, other hormone deficiencies and it was further increasing with age, blood pressure and cholesterol. Interestingly, BMI correlated positively to IGF-I SDS, and therefore did not seem related to severity of the GHD per se, but rather to the nutritional state. The same pattern was seen for the blood pressure and waist circumference. Such correlations have not been demonstrated previously, possibly because it requires very large patient groups as in the KIMS population. Indirect evidence, however, comes from investigations of the acute effect of the growth hormone receptor antagonist pegvisomant on cardiovascular risk factors in healthy persons (45). They suggested that the secondary metabolic changes, e.g. abdominal fat or inflammatory factors that develop as a result of longstanding GHD, are of primary importance in the pathogenesis of atherosclerosis in patients with GHD.

In this analysis, GH replacement therapy reduced the concentrations of total and LDL-cholesterol, but had no significant effect on the concentrations of HDL-cholesterol or triglycerides. This finding is consistent with results reported previously $(25,31,40,46-49)$, but not all are possibly related to a selection of patients with near-normal baseline values (28). The beneficial effects of GH therapy were essentially homogeneous among the different subgroups studied. In other words, they were largely unaffected by variables such as age, sex or the age of onset of GHD. This contrasts with a number of previous findings suggesting that GH replacement has different effects in different subgroups, such as age of onset (43) or gender (50). The homogeneity of therapeutic effects of $\mathrm{GH}$ has been shown before for elderly patients (51) and the additive effect of GH, apart from lipid-lowering drugs has also been demonstrated (52). There was a clear trend of the effects of $\mathrm{GH}$ treatment to be greater after 2 years than after 1 year and be most marked in patients with the most pronounced hypercholesterolaemia at baseline.

Vahl et al. have previously shown that the cholesterollowering effect of $\mathrm{GH}$ is not determined by the concomitant decrease in adiposity, supporting a direct effect of GH on lipoprotein metabolism (40). In support of this, Hana et al. found an increase in lean and a decrease in fat mass in 17 patients with GHD treated over 1 year, without a concomitant change in adipokines and insulin resistance (53). Opposite to this, a randomised, double-blind, placebo-controlled multicentre study of 166 patients with GHD treated 
over 1 year also found a decrease in fat and increase in lean body mass, but in this case with a concomitant reduction in total and LDL-cholesterol (54). Also recently, Abrahamsen et al. demonstrated that the effects of GH replacement on both lipids and body composition were dependent on dose as well as on the obtained IGF-I level (55). Although we did not find any significant reduction in BMI or blood pressure, GH replacement resulted in a beneficial mean reduction of $2.2 \mathrm{~kg}$ of fat and mean increase of $2.2 \mathrm{~kg}$ of lean body mass as well as a small reduction in waist circumference.

The discrepancy between results from BMI and other measures of body composition indicates that BMI is a poor predictor in following the effect of GH therapy compared to waist circumference, BIA and DXA, since a shift from fat to lean body mass will not be reflected in BMI if the total body weight is sustained (56). A favourable effect of $\mathrm{GH}$ replacement on diastolic blood pressure has been demonstrated by Sverrisdottir et al. in a small series of ten GHD patients treated for 1 year (57). A more careful evaluation of blood pressure was done in 22 patients with measurement of 24-hour ambulatory blood pressure (58). Interestingly, they found a preserved circadian rhythm after 12 months of $\mathrm{GH}$ replacement.

The present findings are consistent with previous results showing that $\mathrm{GH}$ replacement can improve dyslipidaemia and other cardiovascular risk factors, and that the effect on both body composition and lipids is sustained over years $(49,54,59,60)$. Quantitatively, a recently published meta-analysis of blinded, randomised, placebo-controlled trials on cardiovascular risk factors in GHD adults found that GH treatment significantly reduced LDL-cholesterol by $-0.5 \mathrm{mmol} / \mathrm{l}$ (vs $-0.4 \mathrm{mmol} / \mathrm{l}$ after 2 years in the present study), total cholesterol by $-0.3 \mathrm{mmol} / \mathrm{l}$ (vs $-0.4 \mathrm{mmol} / \mathrm{l}$ ), fat mass by $-3.1 \mathrm{~kg}$ (vs $-2.2 \mathrm{~kg}$ ), and diastolic blood pressure by $-1.8 \mathrm{mmHg}$ (vs $-0.6 \mathrm{mmHg}$ ), and significantly increased lean body mass by $2.7 \mathrm{~kg}$ (vs $2.2 \mathrm{~kg}$ after 2 years in present study) (31). The metaanalysis and the data from the KIMS database are thus very similar despite differences in methodology.

Taken together, the results suggest that GH replacement therapy may be important in adults with GHD not only to improve the general health and well-being but also to reduce the risk of premature mortality. This has also been indicated very recently by a demonstration of a 1.3 relative risk reduction according to the Framingham equation by 12 months of GH replacement in GHD adults (non-smokers, without diabetes mellitus, hypertension or vascular disease) (61). However, the recorded individual changes in the cardiovascular risk factors in all the studies are small. So, the global benefit of GH replacement on cardiovascular mortality remains to be determined in larger trials with appropriate end points.

\section{Acknowledgements}

The authors express their gratitude to all KIMS investigators for sharing their data.

\section{References}

1 Rosén T \& Bengtsson B-Å. Premature mortality due to cardiovascular disease in hypopituitarism. Lancet 1990336 285-288.

2 Bates AS, Van't Hoff W, Jones PJ \& Clayton RN. The effect of hypopituitarism on life expectancy. Journal of Clinical Endocrinology and Metabolism 199681 1169-1172.

3 Bülow B, Hagmar L, Mikoczy Z, Nordström CH \& Erfurth EM. Increased cerebrovascular mortality in patients with hypopituitarism. Journal of Clinical Endocrinology and Metabolism $1997 \mathbf{4 6}$ 75-81.

4 Bates AS, Bullivant B, Sheppard MC \& Steward PM. Life expectancy following surgery for pituitary tumours. Clinical Endocrinology 199950 315-319.

5 Svensson J, Bengtsson B-Å, Rosen T, Oden A \& Johannsson G. Malignant disease and cardiovascular morbidity in hypopituitary adults with or without growth hormone replacement therapy. Journal of Clinical Endocrinology and Metabolism 2004 89 3306-3312.

6 Tomlinson JW. Holden N. Hills RK, Wheatley K, Clayton RN, Bates AS, Sheppard MC \& Steward PM. Association between premature mortality and hypopituitarism. West Midland Prospective Hypopituitarism Group. Lancet 2001357 425-431.

7 Bengtsson B-Å. Untreated growth hormone deficiency explains premature mortality in patients with hypopituitarism. Growth Hormone and IGF Research $1998 \mathbf{8}$ (Suppl A) 480-485.

8 Beshyah SA \& Johnston D. Cardiovascular disease and risk factors in adults with hypopituitarism. Clinical Endocrinology 199950 $1-15$.

9 Stewart PM \& Sheppard MC. Mortality and hypopituitarism. Growth Hormone and IGF Research 19999 (Suppl A) 15-19.

10 Beshyah SA, Henderson A, Niththyanathan R, Sharp P, Richmond W \& Johnston DG. Metabolic abnormalities in growth hormone deficient adults: carbohydrate tolerance and lipid metabolism. Endocrinology and Metabolism 19941 173-180.

11 Abs R, Bengtsson B-Å, Hernberg-Ståhl E, Monson JP, Tauber J-P, Wilton P \& Wüster C. GH replacement in 1034 growth hormone deficient adults: demographic and clinical characteristics, dosing and safety. Clinical Endocrinology 199950 703-713.

12 Abdu TA, Neary R, Elhadd TA, Akber M \& Clayton RN. Coronary risk in growth hormone deficient hypopituitary adults: increased predicted risk is due largely to lipid profile abnormalities. Clinical Endocrinology 200155 209-216.

13 Beshyah SA, Freemantle C, Thomas E, Rutherford O, Page B, Murphy M \& Johnston DG. Abnormal body composition and reduced bone mass in growth hormone deficient hypopituitary adults. Clinical Endocrinology 199542 179-189.

14 Lonn L, Johansson G, Sjostrom L, Kvist H, Oden A \& Bengtsson B-Å. Body composition and tissue distributions in growth hormone deficient adults before and after growth hormone treatment. Obesity Research 19964 45-54.

15 Jørgensen JO, Pedersen SA, Thuesen L, Jorgensen J, IngemannHansen T, Skakkebaek NE \& Christiansen JS. Beneficial effects of growth hormone treatment in GH-deficient adults. Lancet 19891 1221-1225.

16 Libber SM, Plotnick LP, Johanson AJ, Blizzard RM, Kwiterovich PO \& Migeon CJ. Long-term follow-up of hypopituitary patients treated with human growth hormone. Medicine 199069 46-55.

17 Johansson J-O, Landin K, Tengborn L, Rosén T \& Bengtsson B-Å. High fibrinogen and plasminogen activator inhibitor activity in growth hormone deficient adults. Arteriosclerosis and Thrombosis 199414 434-437. 
18 Leonsson M, Hulthe J, Johannsson G, Wiklund O, Wikstrand J, Bengtsson B- $\AA$ \& Oscarsson J. Increased interleukin-6 levels in pituitary-deficient patients are independently related to their carotic intima-media thickness. Clinical Endocrinology 200359 242-250.

19 Lehmann ED, Hopkins KD, Weissberger AJ, Gosling RG \& Sönksen $\mathrm{PH}$. Aortic distensibility in growth hormone deficient adults. Lancet 1993341309.

20 Markussis V, Beshyah SA, Fisher C, Sharp P, Nicholaides AN \& Johnston D. Detection of premature atherosclerosis by high resolution ultrasonography in symptom free hypopituitary adults. Lancet $19923401188-1192$.

21 Salomon F, Cuneo RC, Hesp R \& Sonksen PH. The effects of treatment with recombinant human growth hormone on body composition and metabolism in adults with growth hormone deficiency. New England Journal of Medicine 1989321 1797-1803.

22 Lonn L, Kvist H, Grangard U, Bengtsson B- $\AA$ \& Sjöström L. CTdetermined body composition changes with recombinant human growth hormone treatment to adult with growth hormone deficiency. Basic Life Science 199360 229-231.

23 Bengtsson B- $\AA$, Abs R, Bennmarker H, Monson JP, Feldt-Rasmussen U, Hernberg-Stahl E, Westberg B, Wilton P \& Wuster C. The effects of treatment and the individual responsiveness to growth hormone replacement therapy in $665 \mathrm{GH}$-deficient adults. Journal of Clinical Endocrinology and Metabolism 199984 3929-3935.

24 Boguszewski CL, Meister LH, Zaninelli DC \& Radominski RB. One year of GH replacement therapy with a fixed low-dose regimen improves body composition, bone mineral density and lipid profile of GH-deficient adults. European Journal of Endocrinology 2005152 $67-75$.

25 Cuneo RC, Salomon F, Watts GF, Hesp R \& Sonksen PH. Growth hormone treatment improves serum lipids and lipoproteins in adults with growth hormone deficiency. Metabolism $1993 \mathbf{4 2}$ 1519-1523.

26 deBoer H, Blok GJ, Voerman HJ, Philips M \& Schouten JA. Serum lipid levels in growth hormone deficient men. Metabolism 199443 199-203.

27 Colao A, di Somma C, Cuocolo A, Spinelli L, Tedesco N, Pivonello R, Bonaduce D, Salvatore M \& Lombardi G. Improved cardiovascular risk factors and cardiac performance after 12 months of growth hormone replacement in young adult patients with GH deficiency. Journal of Clinical Endocrinology and Metabolism 2001861874 1881.

28 Sesmilo G, Biller BM, Llevadot J, Hayden D, Hanson G, Rifai N \& Klibanski A. Effects of growth hormone administration on inflammatory and other cardiovascular risk markers in men with growth hormone deficiency. A randomized, controlled clinical trial. Annals of Internal Medicine 2000133 111-122.

29 Pfeifer M, Verhovec R, Zizek B, Prezelj J, Poredos P \& Clayton RN. Growth hormone treatment reverses early atherosclerotic changes in GH-deficient adults. Journal of Clinical Endocrinology and Metabolism 199984 453-457.

30 Smith JC, Evans LM, Wilkinson I, Goodfellow J, Cockcroft JR, Scanlon MF \& Davies JS. Effects of GH replacement on endothelial function and large-artery stiffness in GH-deficient adults: a randomized, double-blind, placebo-controlled study. Clinical Endocrinology $2002 \mathbf{5 6}$ 493-501.

31 Maison P, Griffin S, Nicoue-Beglah M, Haddad N, Balkau B \& Chanson P. Impact of growth hormone treatment on cardiovascular risk factors in GH-deficient adults: a meta-analysis of blinded, randomised, placebo-controlled trials. Journal of Clinical Endocrinology and Metabolism $2004892192-2199$.

32 Brabant G, von zur Mühlen A, Ranke MB, Kratzsch J, Kiess W, Ketelslegers JM, Wilhelmsen L, Hulthen L, Saller B, Mattson A, Wilde J, Schemer R \& Kann P, German KIMS Board. Serum insulinlike growth factor I reference values for an automated chemiluminescence immunoassay system: results from a multicentre study. Hormone Research 200360 53-60.

33 Lie RF, Schmitz JM, Pierre KJ \& Gochman N. Cholesterol oxidasebased determination, by continuous-flow analysis, of total and free cholesterol in serum. Clinical Chemistry 197622 1627-1630.
34 Lopes-Virella MF, Stone P, Ellis S \& Colwell JA. Cholesterol determination in high-density lipoproteins separated by three different methods. Clinical Chemistry 197723 882-884.

35 Fossati P \& Prencipe L. Serum triglyceride determined colorimetrically with an enzyme that produces hydrogen peroxide. Clinical Chemistry $1982 \mathbf{2 8} 2077-2080$.

36 Friedewald WT, Levy RI \& Fredrickson DS. Estimation of the concentration of low-density lipoprotein cholesterol in plasma, without use of the preparative ultracentrifuge. Clinical Chemistry 197218 499-502.

37 National Cholesterol Education Programm Expert Panel. Executive summary of the third report of the National Cholesterol Education Program (NCEP) Expert Panel on Detection, Evaluation, and Treatment of High Blood Cholesterol in Adults (Adult Treatment Panel III). Journal of the American Medical Association $20012852486-2497$.

38 Johnson WD \& George VT. Effect of regression to the mean in the presence of within-subject variability. Statistics in Medicine 1991 10 1295-1302.

39 Rosén T, Eden S, Larson G, Wilhelmsen L \& Bengtsson B-Å. Cardiovascular risk factors in adults with growth hormone deficiency. Acta Endocrinologica 1993129 201-206.

40 Vahl N, Jorgensen JO, Hansen TB, Klausen IB, Jurik AG, Hagen C \& Christiansen JS. The favourable effects of growth hormone substitution on hypercholesterolaemia in GH-deficient adults are not associated with concomitant reductions in adiposity. A 12 month placebo-controlled study. International Journal of Obesity and Related Metabolic Disorders 199822 529-536.

41 Zeitlhofer J, Doppelbauer A, Tribl G, Leitha T \& Deecke L. Changes of serum lipid patterns during long-term anticonvulsive treatment. Clinical Investigations $1993 \mathbf{7 1} 574-578$.

42 Erfurth EM, Bülow B, Eskilsson J \& Hagmar L. High incidence of cardiovascular disease and increased prevalence of cardiovascular risk factors in women with hypopituitarism not receiving growth hormone treatment: preliminary results. Growth Hormone and IGF Research 19999 (Suppl A) 21-24.

43 Attanasio AF, Lamberts SW, Matranga AM, Birkett MA, Bates PC, Valk NK, Hilsted J, Bengtsson B- $\AA$ \& Strasburger CJ. Adult growth hormone deficient patients demonstrate heterogeneity between childhood onset and adult onset before and during human $\mathrm{GH}$ treatment. Journal of Clinical Endocrinology and Metabolism 1997 $8282-88$.

44 Conceicao FL, de Rooij Mansur VA, Brasil RR \& Vaisman M. Ambulatory monitoring of blood pressure in growth hormone deficient adults. Blood Pressure Monitoring 20027 89-94.

45 Muller AF, Leebeek FW, Janssen JA, Lamberts SW, Hofland L \& van der Lely AJ. Acute effects of pegvisomant on cardiovascular risk markers in healthy men: implication for the pathogenesis of atherosclerosis in GH deficiency. Journal of Clinical Endocrinology and Metabolism 200186 5165-5171.

46 Russel-Jones DL, Watts GF, Weissberger A, Naoumova RP, Myers J, Thompson GR \& Sonksen PH. The effects of growth hormone replacement on serum lipids, lipoproteins, apolipoproteins and cholesterol precursors in adult growth hormone deficient patients. Clinical Endocrinology 199441 345-350.

47 Weaver JU, Monson JP, Noonan K, John WG, Edwards A, Evans KA \& Cunningham J. The effect of low dose recombinant growth hormone replacement on regional fat distribution, insulin sensitivity and cardiovascular risk factors in hypopituitary adults. Journal of Clinical Endocrinology and Metabolism 1995 $80153-159$.

48 Al-Shoumer KA, Gray R, Anyaoku V, Hughes C, Beshyah S, Richmond W \& Johnston DG. Effects of four years' treatment with biosynthetic human growth hormone $(\mathrm{GH})$ on glucose homeostasis, insulin secretion and lipid metabolism in GH-deficient adults. Clinical Endocrinology 199848 795-802.

49 Gibney J, Wallace JD, Spinks T, Schnorr L, Ranicar A, Cuneo RC, Lockhart S, Burnand KG, Salomon F, Sonksen PH \& Russel-Jones D. The effects of 10 years of recombinant growth hormone in adult GH-deficient patients. Journal of Clinical Endocrinology and Metabolism $1999842596-2602$. 
50 Span JP, Pieters GF, Sweep FG, Hermus AR \& Smals AG. Gender difference in rhGH-induced changes in body composition in $\mathrm{GH}_{-}$ deficient adults. Journal of Clinical Endocrinology and Metabolism 200186 4161-4165.

51 Monson JP, Abs R, Bengtsson B- $\AA$, Bennmarker H, Feldt-Rasmussen U, Hernberg-Stahl E, Thoren M, Westberg B, Wilton P \& Wüster C. Growth hormone deficiency and replacement in elderly hypopituitary adults. Clinical Endocrinology 200053 281-289.

52 Florakis D, Hung V, Kaltsas G, Coyte D, Jenkins PJ, Chew SL, Grossman AB, Besser GM \& Monson JP. Sustained reduction in circulating cholesterol in adult hypopituitary patients given low dose titrated growth hormone replacement therapy: a two year study. Clinical Endocrinology 200053 453-459.

53 Hana V, Silha JV, Justova V, Lacinova Z, Stepan JJ \& Murphy LJ. The effects of GH replacement in adult GH-deficient patients: changes in body composition without concomitant changes in adipokines and insulin resistance. Clinical Endocrinology $200460442-450$.

54 Hoffman AR, Kuntze JE, Baptista J, Maum HB, Baumann GP, Biller BM, Clark RV, Cook D, Inzucchi SE, Kleinberg D, Klibanski A, Phil LS, Ridgway EC, Robbins RJ, Schlechte J, Sharma M, Thorner MO $\&$ Vance ML. Growth hormone replacement therapy in adult-onset growth hormone deficiency: effects on body composition in men and women in a double-blind, randomised, placebo-controlled trial. Journal of Clinical Endocrinology and Metabolism 200489 2048-2056.

55 Abrahamsen B, Nielsen TL, Hangaard J, Gregersen G, Vahl N, Korsholm L, Hansen TB, Andersen M \& Hagen C. IGF-I- and sexdependent changes in lipid profile and body composition during GH replacement therapy in adult onset GH deficiency. European Journal of Endocrinology 2004150 671-679.

56 Mersebach H, Rasmussen AK \& Feldt-Rasmussen U. Body composition-methods and effects of growth hormone. In Growth Hormone Deficiency in Adults, pp 117-126. Eds. R Abs \& U FeldtRasmussen, Oxford, UK: Oxford PharmaGenesis Ltd.
57 Sverrisdottir YB, Elam M, Caidahl K, Soderling AS, Herlitz H \& Johannsson G. The effect of growth hormone (GH) replacement therapy on sympathetic nerve hyperactivity in hypopituitary adults: a double-blind, placebo-controlled, crossover, short-term trial followed by long-term open GH replacement in hypopituitary adults. Journal of Hypertension 200321 1905-1914.

58 Ahmad AM, Hopkins MT, Weston PJ, Fraser WD \& Vora JP. Effects of GH replacement on 24-h ambulatory blood pressure and its circadian rhythm in adult GH deficiency. Clinical Endocrinology 200256 431-437.

59 Rosenfalck AM, Maghsoudi S, Fisker S, Jørgensen JO, Christiansen JS, Hilsted J, Volund AA \& Madsbad S. The effect of 30 months of low-dose replacement therapy with recombinant human growth hormone on insulin and C-peptide kinetics, insulin secretion, insulin sensitivity, glucose effectiveness, and body composition in GH-deficient adults. Journal of Clinical Endocrinology and Metabolism $2000854173-4181$.

60 Gotherstrom G, Svensson J, Koranyi J, Alpsten M, Bosaeus I, Bengtsson B-Å \& Johansson G. A prospective study of 5 years of GH replacement therapy in GH-deficient adults: sustained effects on body composition, body mass and metabolic indices. Journal of Clinical Endocrinology and Metabolism 200186 4657-4665.

61 Abdu TA, Elhadd TA, Buch H, Barton D, Neary R \& Clayton RN. Recombinant GH replacement in hypopituitary adults improves endothelial cell function and reduces calculated and relative coronary risk. Clinical Endocrinology 200461 387-393.

Received 28 January 2006

Accepted 6 April 2006 